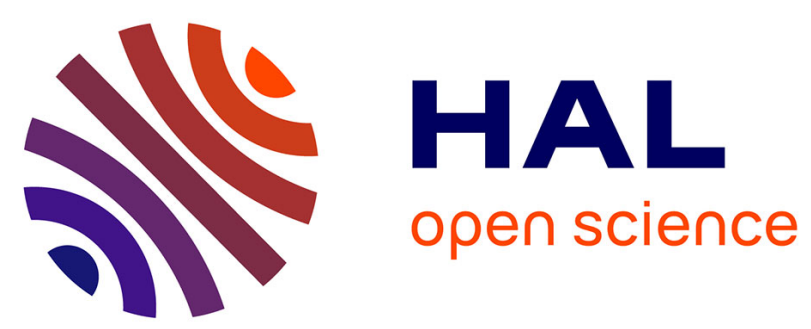

\title{
Comparative study of the male reproductive tract in seven families of South-American catfishes
}

Maurice Loir, Chantal Cauty, Paul Planquette, Pierre-Yves Le Bail

\section{To cite this version:}

Maurice Loir, Chantal Cauty, Paul Planquette, Pierre-Yves Le Bail. Comparative study of the male reproductive tract in seven families of South-American catfishes. Aquatic Living Resources, 1989, 2 (1), pp.45-56. 10.1051/alr:1989005 . hal-02728156

\section{HAL Id: hal-02728156 \\ https://hal.inrae.fr/hal-02728156}

Submitted on 2 Jun 2020

HAL is a multi-disciplinary open access archive for the deposit and dissemination of scientific research documents, whether they are published or not. The documents may come from teaching and research institutions in France or abroad, or from public or private research centers.
L'archive ouverte pluridisciplinaire HAL, est destinée au dépôt et à la diffusion de documents scientifiques de niveau recherche, publiés ou non, émanant des établissements d'enseignement et de recherche français ou étrangers, des laboratoires publics ou privés. 


\title{
Comparative study of the male reproductive tract in seven families of South-American catfishes
}

\author{
Maurice Loir ${ }^{(1)}$, Chantal Cauty ${ }^{(1)}$, Paul Planquette ${ }^{(2)}$ and Pierre Yves Le Bail ${ }^{(1)}$ \\ (1) INRA, Physiologie des Poissons, Campus de Beaulieu, 35042 Rennes Cedex, France. \\ (2) INRA, Laboratoire Hydrobiologie, Campus agronomique, 97387 Kourou, Guyane française
}

Submitted September 2, 1988; accepted January 18, 1989.

Abstract

Résumé
Loir M., C. Cauty, P. Planquette, P.-Y. Le Bail. Aquat. Living Resour., 1989, 2, 45-56.

Specimens belonging to 20 species ( 7 families) of catfishes have been collected in French Guyana. The anatomy and histology of the male reproductive tracts have been studied. In the most primitive species (Helogeneidae, Ariidae) no seminal vesicle is present in the males. In the Pimclodidac, Loricariidae and Callichthyidae (and also in an african Bagridae), there is a progressive transition, going from anterior to posterior in the male tract, from testicular tissue towards round germ cell-free tubules and finally to seminal vesicular tissue. All these families produce round-headed spermatozoa and have external fertilization. The Auchenipteridae and Ageneiosidae are characterized by elongated sperm nuclei, internal fertilization with the aid of a gonopodium and sperm storage in the ovarics. In the Auchenipteridae there is a clear-cut distinction between testes and seminal vesicles. In the Ageneiosidae there is no seminal vesicle, but the dilated deferent duct displays a high secretory activity. Depending on the family and species, the seminal vesicles may carry out either one or both of the two main functions: secretion and sperm storage. In addition, in some species, sperm is also stored in one or two accessory pouches until fcrtilization. The trends that we have observed in the changes in the organization of the reproductive tracts are in agreement with the hypotheses proposed for catfish evolution from comparative anatomical data.

Keywords : Fish, catfish, Siluriformes, South America, reproductive tract, testis, ovary, seminal vesicles, histology, evolution.

Étude comparée du tractus génital mâle chez sept familles de silures sud-américains.

Nous avons collecté en Guyane française des animaux appartenant à 20 espèces ( 7 familles) de silures et nous avons étuđié l'anatomie et l'histologie des tractus génitaux mâles. Les espèces les plus primitives (Helogeneidae, Ariidae) sont dépourvues de vésicules séminales. Chez les Pimelodidae, les Loricariidae et les Callichthyidae (ainsi que chez un Bagridac africain), lo tissu testiculaire, localisé antérieurement, est progressivement remplacé vers l'arrière par un tissu à caractères de vésicules séminales. Chez toutes ces familles, le noyau des spermatozoïdes est sphérique et la fécondation est externe. Les Auchenipteridae et les Ageneiosidae sont caractérisés par des spermatozoïdes à noyau allongé, une fécondation interne réalisée à l'aide d'un gonopode et l'existence d'un stockage des spermatozoïdes dans les ovaires. Chez les Auchenipteridac les testicules sont nettement distincts des vésicules séminales. Chez les Ageneiosidae les vésicules sont absentes mais la partie postérieure du canal déférent est élargie et possède une activité secrétoire. Selon les familles, les vésicules séminales assureraient soit le stockage des spermatozoïdes soit une fonction de secrétion, soit simultanément les deux fonctions. En outre, chez certaines espèces les spermatozoïdes sont aussi stockés dans une ou deux poches anncxcs. L'ćvolution quc nous avons observée quant à l'organisation du tractus génital mâle et aux modalités de la reproduction sont en accord avec les hypothèses proposées pour l'évolution des Silures à partir de données anatomiques.

Mots-clés : Poisson, silure, Amérique du Sud, tractus génital, testicule, ovaire, vésicule séminale, histologie, évolution. 


\section{INTRODUCTION}

The Ostariophysii is the dominant freshwater fish group in the world in general and in South America in particular. In the latter continent, Siluriformes (catfishes) - one of the two orders of Ostariophysii-are represented by 14 families. The systematics and evolution of these catfishes are poorly known. This is also true for the biology and physiology of most of the species which are not potential candidates for fish farming. All phylogenic studies dealing with these fishes have taken anatomical data into consideration and, in some scarce cases, embryological data. In the present state of our knowledge, two main sets of working hypotheses concerning catfish evolution have been proposed by Chardon in 1968 and by Gosline in 1975.

In most Siluriformes, seminal vesicles are present in the male. These organs have been histologically studicd for six species only, fivc bcing found in Africa and Eurasia (for review see Van den Hurk et al., 1987) and only one in South America (Parauchenipterus galeatus; Chacon and Mendes Filho, 1972). No comparative study of the accessory organs - and in general of the male genital tract-has been carried out on catfishes. For the females, only one paper has briefly mentioned the presence of spermatozoa in the ovary of one Auchenipteridae (Chacon and Mendes Filho, 1972).

We have had the opportunity to collect specimens from 20 siluroid species ( 7 families) in French Guyanan freshwaters and coastal waters and to study the histology of the male genital tracts. It appears that spermatogenesis usually develops according to the general pattern known for fishes (testes of the unrestricted spermatogonial, lobular type; Grier, 1981; Billard, 1986). In this paper, we have focused our attention on the evolution of the morphology and structure of the seminal vesicles and also of the other accessory organs participating in the male tract in some species. Furthermore, we have examined some original aspects of the reproductive biology of these fishes. In this respect we have looked for the presence of spermatozoa in the ovaries of females to ascertain the occurrence of internal fertilization where the males have a gonopodium. Since it appears that the Bagridae (not present in South America) represent an evolutionary step which has not been found in the Guyanan catfishes that we have collected, Chrisichthys nigrodigitatus was also included in our study.

In general, the trends that we have demonstrated in the evolution of the male tract and of the reproductive biology are in agreement with the evolutionary relationships of the Siluriformes families proposed on the basis of comparative anatomical data.

\section{MATERIAL AND METHODS}

Specimens from 17 species of Siluriformes fishes have been collected in three French Guyana rivers (Kourou, Maroni and Oyapock), in December and

Table 1. - Siluriformes species considered in this study (in brackets: number of males).

\begin{tabular}{|c|c|}
\hline Families & Species \\
\hline Helogeneidae & Irelogenes marmoratus Günther (5) \\
\hline \multirow[t]{3}{*}{ Ariidae } & Arius proops (Valenciennes in C.V.) (58) \\
\hline & Arius parkeri (Trail) (40) \\
\hline & Arius couma (Valenciennes in C.V.) (16) \\
\hline Bagridae & Chrysichthys nigrodigitatus (Lacépède) (2) \\
\hline \multirow[t]{5}{*}{ Pimelodidae } & Pimelodella cristata (Müller \& Troschel) (4) \\
\hline & Pimelodus blochii Valenciennes in C.V. (4) \\
\hline & Pimelodus ornatus Kner (3) \\
\hline & $\begin{array}{l}\text { Pseudopilemodus raninus (Valenciennes in C.V.) } \\
\text { (2) }\end{array}$ \\
\hline & Rhamdia quelen (Quoy \& Gaimard) (2) \\
\hline \multirow[t]{3}{*}{ Loricariidae } & Hypostomus gymnorynchus (Norman) (2) \\
\hline & $\begin{array}{l}\text { Pseudoancistrus barbatus (Valenciennes in C.V.) } \\
\text { (1) }\end{array}$ \\
\hline & Harttia surinamensis Boeseman (2) \\
\hline \multirow[t]{3}{*}{ Callichthyidae } & Corydoras sp. (3) \\
\hline & Hoplosternum littorale (Hancock) (5) \\
\hline & $\begin{array}{l}\text { Hoplosternum thoracatum (Valenciennes in C.V.) } \\
\text { (4) }\end{array}$ \\
\hline \multirow[t]{4}{*}{ Auchenipteridae } & $\begin{array}{l}\text { Auchenipterus nuchalis (Spix in Spix \& Agassiz) } \\
\text { (3) }\end{array}$ \\
\hline & Parauchenipterus galeatus (Linnaeus) (15) \\
\hline & Pseudauchenipterus nodosus (Bloch) (3) \\
\hline & Tatia brunnea Mees (1) \\
\hline Ageneiosidae & Ageneiosus brevifilis Valenciennes in C.V. (6) \\
\hline
\end{tabular}

in March (1984, 1985, and 1986) (table 1). Specimens from three species of Ariidae were netted in French Guyana coastal seawaters throughout the year (19821983). Chrysichthys nigrodigitatus specimens were obtained from a fish farm in the Ivory Coast. The males that we have studied were either mature or almost mature. In addition, some were juvenile or in a regressed stage.

After dissection, under a binocular magnifier if necessary, the male and female genital tracts were fixed either in aqueous Bouin or in Bouin Holland, either in toto or in several pieces corresponding to the different visible parts. After embedding in Paraplast, sections were stained with Regaud Hematoxylin, Orange $\mathrm{G}$ and Aniline blue.

\section{RESULTS}

\section{Helogeneidae}

For Helogenes marmoratus, the testes appear as two elongated pouches ( 3 to $5 \mathrm{~mm}$ long in mature males $55-65 \mathrm{~mm}$ long) with a lightly lobated profile (fig. 1). They converge towards a short genital papilla. The deferent canal is extremely short. There 

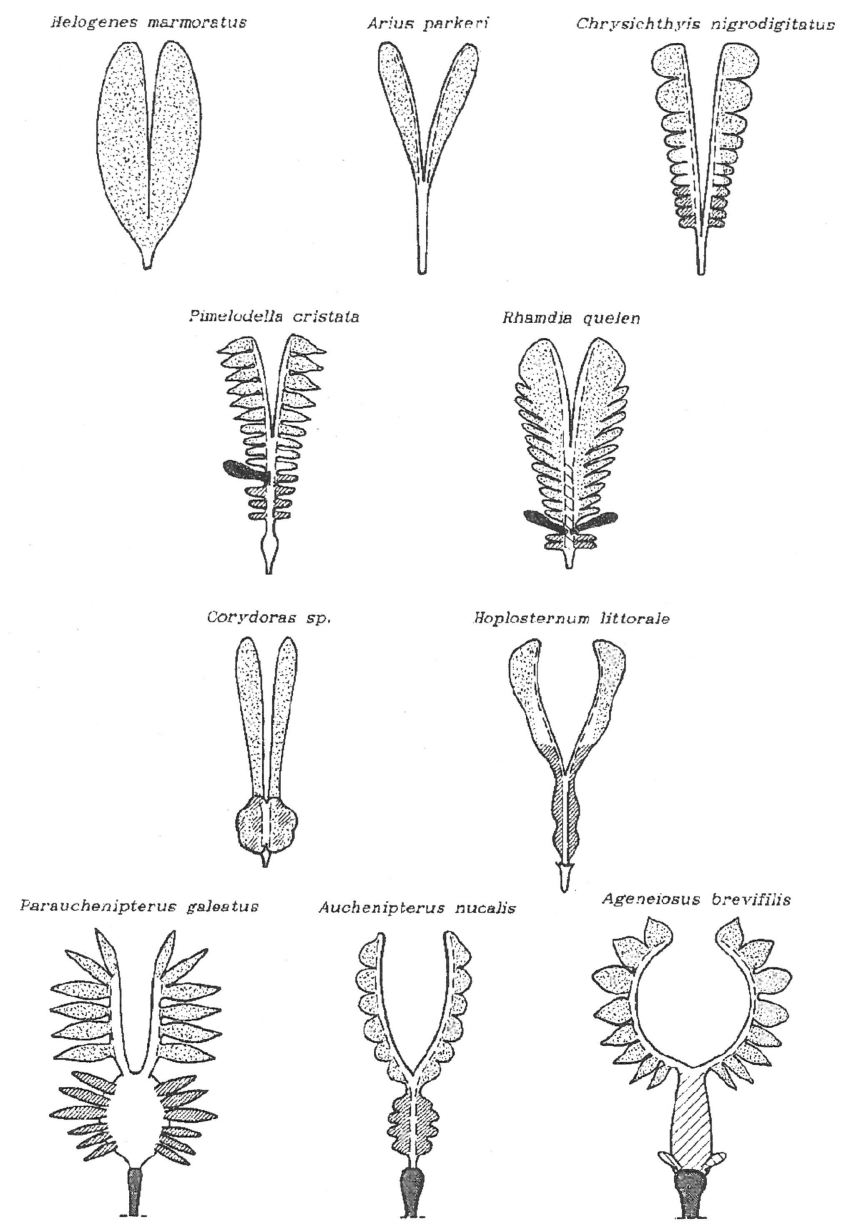

Ageneiosus brevifilis
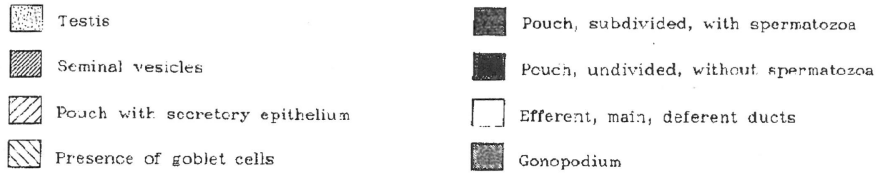

Figure 1. - Schematic morphology and organization of the male tracts of some Siluriformes.

are no seminal vesicles. No efferent ducts were observed. The albuginea is particularly thick. In mature males caught in December, the interstitium is welldeveloped and interstitial cells with a small round nucleus are scattered in this tissue. The sperm nucleus is spherical.

\section{Ariidae}

For the three studied species, the anatomy of the testes is roughly similar to that observed on H. marmoratus and, in particular, there are no seminal vesicles. However, a main duct runs along every testis and the deferent duct is longer, being equal to about one half of the testis length ( fig. 1). According to the maturation stage, the testis varies from a thin filament (Gonadosomatic index, GSI lower than $0.07 \%$ ) to a whitish $1 \mathrm{~cm}$ wide pouch (GSI $=0.15$ $0.30 \%$ ). At sexual rest, only A spermatogonia are present in the tubules, while at spermiation, the tubular lumen is filled with spermatozoa, the nuclei of which are spherical. Interstitial cells, supposed to be Leydig cells, are usually observed in clusters, scattered among conjunctive fibers. Their histology varies in parallel with the maturation stages; the nuclei are small and have an irregular profile in regressed testes (June-July) while they are large and spherical or ovoid in spermiating testes (December-February).

\section{Bagridae}

For the male Chrysichthys nigrodigitatus the genital tract is composed of two elongated "testes" ( fig. 1). They have a foliate appearance with flattened lobes disposed along a stalk. In the anterior part of the "testes", there are some wide lobes. In the posterior part they are much more narrow while in the median part they have an intermediate width. 
From light microscopy, it appears that the anterior lobes correspond entirely to testicular tissue. Spermatogenesis develops in tubules which are separated by a conjunctive tissue where groups of interstitial cells are clearly visible. Spermatozoa have a spherical nucleus. At the base of the lobes, in the "stalk", the tubules converge towards a convoluted main duct lined by a thick epithelium. In the median part this organization is nearly identical. However, tubules apparently similar to testicular tubules are present at the base of the lobes, but these are devoid of any round germ cell. They are simply lined by a rather thin homogeneous epithelium and are filled with spermatozoa. In the posterior part, testicular tissue is restricted to the apex of the lobes which are mainly constituted by germ cell-free tubules identical to those described above (plate 1-1). The epithelial cells have a discrete secretory activity. In the lumen of the tubules either some spermatozoa or a light secretory material are present. Some interstitial cells are scattered between the tubules.

\section{Pimelodidae}

According to the species, each of the "testes" is composed of a variable number of pear-shaped, more or less elongated, lobes disposed along a stalk ( fig. 1). The two "testes" coalesce in the posterior part and they are connected to the genital papilla by a more or less long structure which also bears smaller lobes. For some species, one or two pouches are appended ventrally to this structure. In the males, the GSI (total genital tract) is always lower than $1 \%$ (it is usually between 2 and $7 \%$ for the females).

In the various studied species, the testicular tubules have a rather high diameter and the spermatogenic cysts are loosely disposed against the basal lamina. In the males collected in December and March, the interstitium is very reduced and interstitial cells are scarcely observed. The spermatozoa have a spherical nucleus.

For Pimelodella cristata, the anterior lobes are testicular lobes ( fig. 1). When present in the lumen of the tubules, the spermatozoa are not mixed with extracellular material. It should be noted that some spermatozoa have a nuclcus two to four times larger than normal. Moving posteriorly, from the place where the two main ducts coalesce in a single duct, the histology of the lobes becomes progressively intermediate between testis and seminal vesicles (plate 12) and only some rare spermatogonia are visible in the tubules. Spermatozoa present in the lumen are mixed with an amorphous material and some cellular debris. Posteriorly, an elongated pouch is connected to the single deferent canal. It has a muscular wall, building up inner villi and covered by a pluristratified epithelium. This epithelium appears to be able to desquamate partly or completely and cellular remnants are mixed with spermatozoa present in the lumen of the pouch (plate 1-3). Furthermore, spermatozoa nuclei are inserted in the epithelial cells. In the posterior part of the genital tract are small lobes, sometimes tightly packed in a small mass surrounding the deferent canal. These are exclusively seminal vesicles. The tubules which do not have a large diameter are lined by an unistratified epithelium. An amorphous secretory matcrial (mcrocrinc sccretion) is present in the lumen. At the apex of the seminal vesicles this material is usually alone, while in the basal part more or less spermatozoa are mixed with it.

For Pimelodus ornatus the genital tract differs from that of $P$. cristata in the following way: the testicular part is proportionally longer. In the tubule lumen and in the main ducts the spermatozoa are mixed with a discrete material in which cellular remnants are visible. The pouch is short and wide instead of being elongated, but its histology and content are identical. The last lobes before the pouch have an intermediate structure between testis and seminal vesicles. The seminal vesicles are located at the level of the pouch and posteriorly. In these organs the epithelium lining the tubules is unistratified and the cells have a large round nucleus. More or less scattered spermatozoa mixed with flocculent material and many cellular remnants (holocrine secretion) are present in all the tubules. Between the tubules there are mainly conjunctive fibers, but also a few cells in which the nucleus is similar to that of the interstitial testis cells.

For Pimelodus blochii, the anatomy and histology of the male genital tract are essentially similar to those described for P. ornatus. However, in the seminal vesicles, which have a thin wall and often very large tubules, the epithelial cells produce an abundant secretory globular, possibly colloidal material (merocrine secretion) which mixes with the spermatozoa present in the lumcn (plate 1-4). The nucleus of the epithelial cells is typically polylobate. Some interstitial cells are present between the tubules.

For Pseudopimelodus raninus, no pouch has been observed. However, in the posterior "testis" part, where seminal vesicles replace the testicular lobes, the deferent duct is replaced by a cylindrical hollow structure. The wall of this structure builds up longitudinally-oriented highly developed villi. The epithelium which covers them is constituted by tall cells. In addition, goblet cells (mucous cell-like) which produce some secretory material are scattered along the epithelium (plate 1-5). This subdivided deferent duct extends to the genital papilla, but between the last seminal vesicles and the papilla it is surrounded by a muscular mass. The seminal vesicles are constituted mainly by few large tubules, the wall of which is convoluted, and which are separated by an extremely reduced interstitial tissue. The epithelial cells secrete a colloidal bubbly material (merocrine secretion). No spermatozoa has been seen in the seminal vesicles.

Rhamdia quelen differs from the above Pimclodidac in several points. 1) The "testes" are made up of a large number of thin lobes (fig. 1). 2) The spermatozoa do not have a spherical nucleus but an ovoid one (length $=2$ diameters). 3) At maturity, enormous 

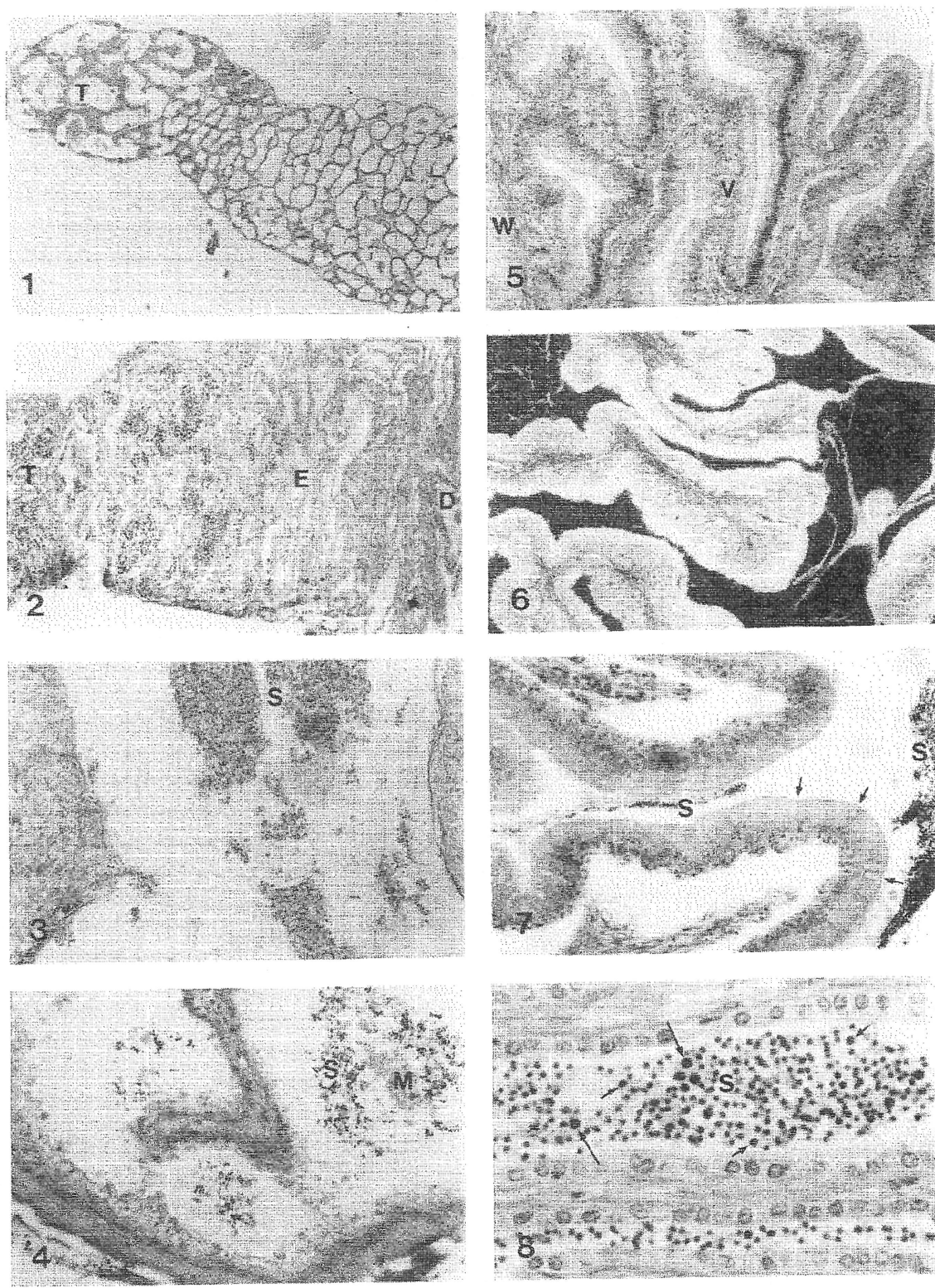
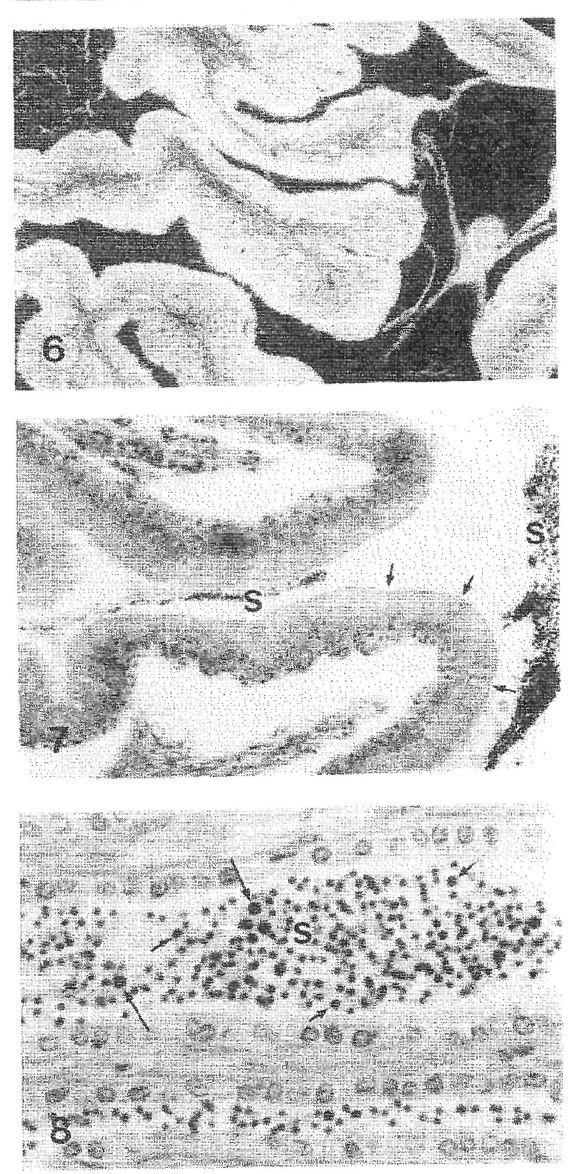

Plate 1. - 1: Chrysichthyis nigrodigitatus. One posterior lobe. Testicular tissue (T) is restricted to the apex $\times 32$. 2: Pimelodella cristata. Intermediate lobe. The testicular tissue (T) is related to the main duct (D) through tubules mainly devoid of round germ cells (E) $\times$ 53. 3: Pimelodella cristata. Inside of the "pouch". Spermatozoa (S) between the villi are mixed with cellular debris. The epithelium is mostly desquamated $\times$ 70. 4: Pimelodus blochii. Seminal vesicle. Detail of one tubule. Spermatozoa (S) mixcd with secretory material (M) $\times$ 240. 5: Pseudopimelodus raninus. "Deferent duct". Long, highly digitated villi (V) originating from the wall (W). Arrows: goblet cells $\times 140$. 6: Rhamdia quelen. Efferent ducts filled with tightly packed spermatozoa $\times 150$. 7: Rhamdia quelen. Posterior part of the "deferent duct". In the lumen, spermatozoa (S) more or less embedded in secretory material. Goblet cells (arrows) scattered at the surface of the epithelium (which is artefactually disconnected from the conjunctive tissue) $\times 240$. 8: Hoplosternum thoracatum. Spermatozoa (S) in the lumen of the main duct. Some nuclei are twice (small arrows) or four times (long arrows) larger $\times 580$. amounts of spermatozoa are present in the dilated seminiferous tubules. 4) Two pouches instead of one are present in the posterior part of the genital tract.

The interstitial tissue is very reduced in males caught in December. At the basal part of the testicular lobes the tubules are connected to the main duct by tubules lined by a thick epithelium devoid of germ cells (efferent ducts; plate 1-6). At the end of the "testis", the deferent duct is replaced by a tubular structure with inner villi, similar to that described for $P$. raninus excepted that there are more goblet cells in the epithelium (plate 1-7). The two posterior pouches connect to the modified deferent duct. They are elongated, tubular and the inside is unsubdivided. They Vol. $2, n^{\circ} 1-1989$ have a conjunctivo-muscular wall. The epithelium does not possess goblet cells. No spermatozoa were observed in the pouches which contain an amorphous matcrial mixed with cellular debris. Posteriorly to these pouches, several seminal vesicles, but also some testicular lobes, as well as the posterior part of the modified deferent canal, are completely surrounded by a thick, well individualized muscular mass. Seminal vesicles are composed of very wide tubules separated by a reduced interstitial tissue. Tubules contain a light flocculent secretory material (merocrine, but also holocrine secretion). No spermatozoa were seen in the seminal vesicles. 


\section{Loricariidae}

Only onc or two males of each of the three studied species have been collected, and furthermore it has not been possible to study accurately the anatomy of the genital tracts. Nevertheless, it appears that the male tract is characterized by, 1) long and thin testes localized in the anterior part, 2) poorly defined seminal vesicles localized in the posterior part where the deferent duct is somewhat enlarged.

The histology of spermatogenesis does not differ clearly fom that described for Pimelodidae and the spermatozoa have a spherical nucleus. In the anterior part, the tubules are preferentially oriented longitudinally. The interstitial tissue is well developed in males caught in December.

In the posterior part of the tract, the relationship between the enlarged testes and the seminal vesicles is not clear, but it seems that it is the basal parts of the testes which are differentiated and fulfill the function of seminal vesicles: the tubules become larger and devoid of germ cells. The unistratified layer of somatic cells lining the tubules become secretory. Spermatozoa seen in the main ducts are then embedded in an homogeneous substance.

For Hypostomus gymnorhynchus especially, the posterior part of the main ducts, before they join, has a remarkable inner epithelium which builds up numerous microvilli. Most of the cells covering these villi are goblet cells which expel secretory material into the lumen. The posterior deferent duct, after the two main ducts have joined, is a wide canal with a thick conjunctive wall. The inner epithelium also builds up microvilli covered by epithelial cells which secrete (merocrine secretion) a flocculent material.

\section{Callichthyidae}

In the three studied species the histology of spermatogenesis is similar to that described in the previous species. Spermatozoa have a spherical nucleus. It should be noted that for Hoplosternum thoracatum a small proportion of sperm nuclei, but also of spermatid nuclei is consistently observed to be about 2 or 4 or even 8 times larger than the others (plate 1-8). This is not the case for $H$. littorale. It should also be noted that for Corydoras sp. the germ cells are larger than for any other species. In mature testes, the interstitium is moderately developed and interstitial cells have conspicuous round nuclei.

For Corydoras sp. the anatomy and histology of the genital tract have similarities with those described for the Loricariidae. Indeed, in the anterior part, both testes are elongated and have a small diameter (fig. 1). Tubules are longitudinally oriented. In the posterior lightly lobated mass the distinction between testicular tissue and seminal vesicles is not evident. In some parts, some spermatogonia, and occasional spermatocytes, spermatids and even spermatozoa are present in the tubules. In spite of this, the somatic cells (Sertoli cells?) secrete a colloidal substance, in variable amounts depending on the tubules (plate 29).

For Hoplosternum sp., the male genital tract consists of two elongated lightly lobated and flattened testes which join posteriorly in a segment which goes towards the genital papilla ( fig. 1). The posterior part of this segment is surrounded by a mass composed of several packed seminal vesicles. The tract ends in a short ( 5 to $8 \mathrm{~mm}$ long) retractile conjunctivomuscular external appendix. For $H$. littorale mature males, the GSI (total genital tract) is around $1 \%$, while it is equal to $5-14 \%$ in wild mature femalcs and to $20-25 \%$ in females grown in ponds.

The anterior lobes consist entirely of testicular tissue. Moving posteriorly, increasing lengths of tubules become progressively devoid of germ cells, starting from the main ducts. These tubules may be considered as equivalent to efferent ducts. Simultaneously, the conjunctive tissue between tubules becomes morc prominent and some nuclei identical to those of the interstitial testicular cells are visible. At the end of the anterior part there is no more testicular tissue but only tubules, the basal part of which is similar to efferent ducts and the apical part of which secretes (merocrine secretion) an homogeneous material i.e. having the same activity as seminal vesicle tubules.

In the posterior part of the tract, seminal vesicles are tightly packed around the unique deferent duct. In their part, tubules are wide and filled with a secretory material similar to that mentioned above (plate 2-10). They are devoid of spermatozoa. In the basal part, tubules are narrower and contain numerous spermatozoa embedded in the same secretory substance (plate 2-10). In the deferent duct, which is lined by a pluristratified epithelium, they are also so embedded.

\section{Auchenipteridae}

This family differs from the preceeding ones in the following points:

- Spermiogenesis is characterized by complex morphological cellular changes leading to the production of spermatozoa with a long, thin and often straight nucleus. However, for Auchenipterus nuchalis spermatid nuclei have a curved profile at some maturation stage. For Tatia brunnea, the posterior part of the nucleus is wider than the anterior one which appears to be lightly helical. In addition, in this species, the spermatozoa are gathered in bundles, the nuclei being bound together.

- In the testicular lobes, the seminiferous tubules show a tendency to be radially oriented and in some species it is clear that tubules similar to efferent ducts, that is without round germ cells, but filled with mature spermatozoa, are disposed at the periphery of every lobe (plate 2-11) and convergc towards their basal part where the main duct is. This suggests that sperm cells are not collected from testes in the classical way but according to an orignal one. The genital 
tract ends in a roughly cylindrical gonopodium which possesses an internal canal and which corrcsponds to the first ray of the anal fin. This observation argues in favour of internal fertilization.

- Spermatozoa are usually present in mature ovaries which display more or less differentiated structures to favour sperm storage.

In the different species, the male genital tract is organized on a similar pattern: testes consist of two chaplets of testicular lobes (fig. 1). The two main ducts, as well as several seminal vesicles, open in a usually large ampulla which is prolonged as a narrow canal extending throughout the gonopodium.

Morc data have been collected for males of Parauchenipterus galeatus than for the other species. It seems that for this species the total number of testicular lobes ( fig. 1) may vary in mature males between 13 and 44 without relation with the size of the animals, while the number of the seminal vesicles varies between 14 and 20 . In addition, the colour and morphology of the testicular lobes and seminal vesicles is variable. The anterior vesicles are usually pink, while the posterior ones are rather white and smaller. The weight of the ampulla plus the seminal vesicles may be up to 8 times higher than that of all of the testicular lobes.

As opposed to the preceeding species, the GSI can be very high in male $P$. galeatus, varying between 1.3 and $6.5 \%$ (testes only) or between 9 and $13 \%$ (genital tract) for mature males. For mature females it varies between 4 and $20 \%$. For Pseudauchenipterus nodosus it may be equal to $10 \%$ (genital tract) for mature males and $25 \%$ for mature females.

In the Auchenipteridae the histology of spermatogenesis is characterized by tubules almost completely filled by the cysts ( 2 to 5 in a cross-section) so that, quite unlike of the Pimelodidae, the tubule lumen is of ten more or less occluded (plate 2-12). In mature spermiating males, A spermatogonia are scattered at the periphery of the tubules. Cysts contain large numbers of spermatocytes or spermatids and the nuclei are tightly packed, suggesting a high nucleo-cytoplasmic ratio. Sertoli nuclei are exceptionally observed in mature testes. Elongated spermatid nuclei are often regularly disposed, resulting from an orientation of all of the tips of the nuclei towards the periphery of the cyst (plate 2-12). The interstitial tissue is always extremely reduced in mature males collected in December and March.

In Auchenipterus nuchalis (fig. 1) seminal vesicles are short and broad and packed as a mass around the ampulla, which has a reduced diameter and volume but a thick conjunctive wall. They consist only of some very wide tubules lined by a thick epithelium. Usually the tubules are filled with spermatozoa embedded in an either compact or sometimes bubbly material also containing cellular remnants (holocrine but also merocrine secretion). Some tubules arc devoid of spermatozoa.
In Pseudauchenipterus nodosus, the ampulla is not wide. Its thick conjunctive wall builds up short microvilli which are covered by a thick epithelium. Spermatozoa, often pointing their nuclei towards that of the cell, are enclosed in the epithelial cells. Numerous spermatozoa free of any material are present in the lumen of the ampulla, although some large masses of a dense colloidal substance are scattered among them. The seminal vesicles are made up of several rather narrow tubules with a usually thin epithelium which, however, is sometimes similar to that of the pouch. Large homogeneous colloidal masses and free spermatozoa are in all the tubules, sometimes in large numbers. Some interstitial cells are scattered between the tubules.

The structural organization of the ovary in $P$. nodosus is particularly unusual. The epithelium of the ovary lamellac is differentiated in two different ways. At the outside of the lamellae, at the point of contact with the follicular envelopes of the oocytes, the cells which have a moderate height contain numerous spermatozoa deeply inserted in their cytoplasm (plate 2-13 and 14). The epithelium also builds up deep digitated invaginations into the lamellae (plate 2-13). They are lined by high cells which apparently secrete in an holocrine way a material which envelopes the spermatozoa present in the lumen. Usually few if any spermatozoa are inserted in these cells.

For mature male $P$. galeatus the anterior seminal vesicles consist of tubules with a diameter approaching that of the testicular tubules. They are radially oriented in the centre and longitudinally oriented at the periphery. Their epithelium has a variable height. An homogeneous, possibly colloidal material due to merocrine secretion by the epithelial cells is present in all the tubules, although it seems that these cells would also secrete in a holocrine way. Some interstitial cells are scattered between the tubules. The posterior seminal vesicles differ from the anterior ones in the following points:

- the conjunctive tissue between the tubules is thicker, but no interstitial cells are visible any more;

- the diameter of the tubules is somewhat greater;

- less or no secretory material is visible in the tubules while spermatozoa are present; some of them are gathered in small groups, being bound together by the tip of their nuclei.

The ampulla (vesicula gelatinosa; Chacon and Mendes Filho, 1972) may be $3 \times 4 \mathrm{~cm}$ large and is subdivided by long villi. It has a thick conjunctive wall. In mature males it is filled with free spermatozoa and with a translucent, whitish, gelatinous material in which spermatozoa are scattered. In fact, this material is composed of small masses with spermatozoa insertcd in their surface. This mixture or "milt" is easily expelled from spermiating males by a light abdominal pressure.

It should be noted that in an immature male, the histology of the testicular lobes was similar to that of the seminal vesicles, except that spermatogonia and 

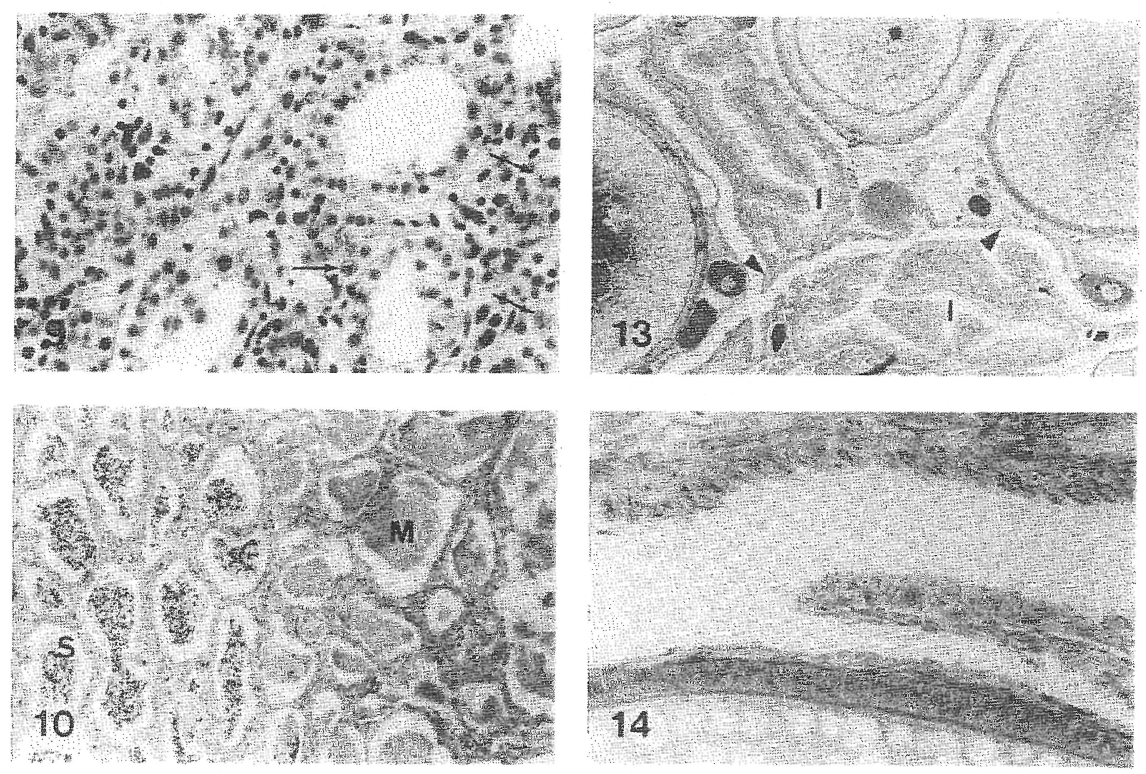

Plate 2. - 9: Corydoras sp. Tissue with characters of seminal vesicles and with some spermatogonia (arrows) in the epithelium of the tubules $\times 340$. 10: Hoplosternum littorale. Seminal vesicle. Secretory material $(\mathrm{M})$ in the apical part of the tubules and spermatozoa mixed with identical material (S) in the basal part of the tubules $\times 150$. 11: Pseudauchenipterus nodosus. Apical part of a testicular lobe. Testicular tissue (T) and at the periphery, efferent ducts filled with spermatozoa (E) $\times$ 45. 12: Pseudauchenipterus nodosus. Testicular tissue. Cysts of round and elongated spermatids. Note 2 cysts with concentrically-oriented spermatid nuclei $\times 165$. 13: Pseudauchenipterus nodosus. Ovary. Arrowheads: thin epithelium of the ovary lamellae. (I) digitated invaginations of the epithelium $\times 50$. 14: Pseudauchenipterus nodosus. Ovary. Detail of the epithelium of the lamellae. Note the numerous sperm heads inserted in the cells $\times 280$. 15: Parauchenipterus galeatus. Ovary lamellae. (O) previtellogenic oocyte. Spermatozoa (S) in the lumen or inserted in the cpithelial cells $\times 200$. 16: Ageneiosus brevifilis. "Deferent duct". Detail of the long, highly digitated villi. In the lumen, spermatozoa mixed with secretory material $\times 110$.

some spermatocytes were present in the testicular tubules while they were absent in the seminal vesicular tubules. In the two organs the tubules had a small diameter and the interstitial tissue was developed.

In the females, the structure of the ovary is not as complex as for $P$. nodosus. Indeed, the epithelium of the ovary lamellae does not display special differentiation. All epithelial cells are similar, differing only in their height. It does not seem that they secrete any material. Numerous spermatozoa, sometimes tightly packed together, are present between the lamellae. They are usually alone but are sometimes associated with a light flocculent material. Furthermore, in some places, bundles of spermatozoa have the anterior part of their nuclei inserted in the epithelial cells (plate 215). No spermatozoa are present in previtellogenic ovaries.

\section{Ageneiosidae}

The morphology of the anterior part of the genital tract, that is the testes, of A. brevifilis is similar to that described for the Auchenipteridae (fig. 1). However, the posterior part is different. Indeed, the two main ducts open in a long, roughly cylindrical, ampulla which corresponds to the deferent duct and which ends in a gonopodium. Two short elongated appendices are connected at the end of this structure. 
For mature males and mature females the GSI (total genital tract) is around $2-3 \%$. The histology of spermatogenesis and the structural organization of the testicular lobes are identical to those described in the Auchenipteridae.

The long ampulla has a thick conjunctive wall. The inside is subdivided by very digitated long villi. These villi are sustained by a well-developed conjunctive tissue (plate 2-16). In mature males the spaces between the villi are wide and the epithelial cells which cover them secrete (holocrine secretion) a flocculent but rather globular material. Numerous spermatozoa are prescnt everywhere between the villi, mixed with secretory globules. In immature males the spaces between the villi are more narrow, but the cells secrete abundantly.

The two posterior small appendices have a thick conjunctive and muscular wall. They are glandular organs. The lumen is radially digitated and lined by a high unistratified epithelium which contains goblet cells (plate 3-17). The glandular lumen is filled with an homogeneous secretory material. These glands open into the posterior end of the ampulla. A narrow canal extends longitudinally throughout the gonopodium.

In females, the structural organization of the ovary is classical. The epithelium of the ovary lamellae is thin and not especially differentiated, except at the bottom of the interlamellae spaces where the cells are taller. In mature females, masses of packed spermatozoa either without additional material or embedded in a light substance, are usually visible in front of these cells (plate 3-18) and are also scattered in the interlamellar spaces. Small bundles of spermatozoa are sometimes inserted in the epithelial cells along the lamellae.

\section{DISCUSSION}

\section{Spermatogenesis and biology of reproduction (table 2)}

In six (Helogeneidae, Ariidae, Bagridae, Pimelodidae, Loricariidae and Callichthyidae) of the eight families considered in this study, the sperm nucleus is spherical. The absence of a gonopodium and of spermatozoa inside the ovaries indicate that fertilization lakes place external to the body of the female. In contrast, in the two other families, Auchenipteridae and Ageneiosidae, the sperm nucleus is conspicuously elongated and, as already indicated, for at least one species ( $P$. galeatus, Chacon and Mendes Filho, 1972) fertilization takes place within the female reproductive tract with the aid of a gonopodium.

Species of several fish families were already known to display internal fertilization and viviparity (Breder and Rosen, 1966). In general, spherical headed spermatozoa are thought to be evolutionarily primitive and correlated with external fertilization. By contrast, elongated sperm heads are thought to be more

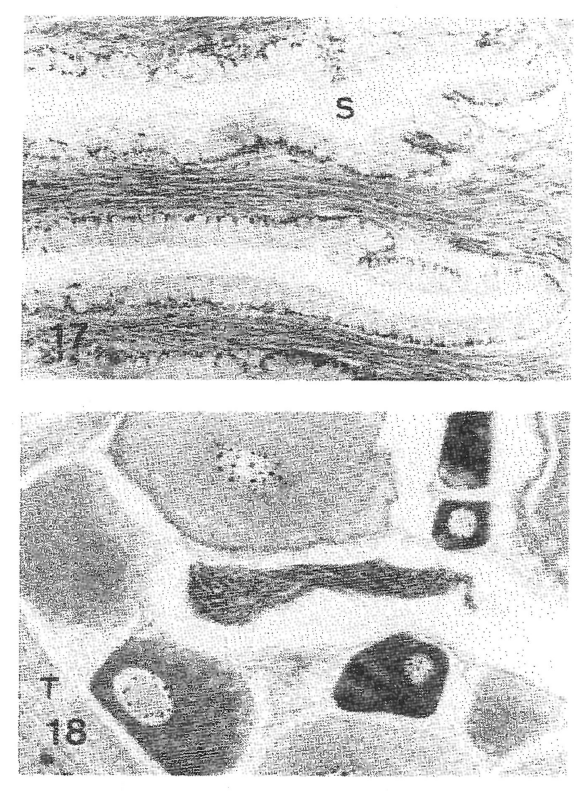

Plate 3. - 17: Ageneiosus brevifilis. Posterior gland. Numerous goblet cells cover longitudinally oriented cryptae. (S) secretory material $\times 150$. 18: Ageneiosus brevifilis. Ovary. Spermatozoa gathered at the bottom of an intcrlamellar space. (T) ovary tunica $\times 160$

advanced inasmuch as they are correlated with internal fertilization and viviparity. Our observations confirm that such a relationship "shape of the sperm head/biology of reproduction" is also valid for at least two families of catfishes. However, three points are to be noted. 1) The Auchenipteridae and Ageneiosidae that we have studied exhibit internal fertilization but according to our observations, and in agreement with Chacon and Mendes Filho (1972), they are oviparous spawning eggs which have been fertilized in the ovary. 2) While in the viviparous Atheriniformes the testis is of the "restricted spermatogonial type" (Grier, 1981; spermatogonia are restricted to the distal end of the seminiferous tubules), in Auchenipteridae and Ageneiosidae it is of the "unrestricted spermatogonial type" (spermatogonia occur along the length of the seminiferous tubules). 3) These Siluriformes species have a tubular gonopodium. Concomitantly, spermatozoa are usually not organized in either spermatophores or spermatozeugmata (for Tatia brunnea they are however gathered in bundles, being stuck together by their nuclei). This situation is similar to those observed in advanced Anablepidae and Grier (1981) has proposed that a "tubular gonopodium obviates the necessity of producing either spermatozeugmata or spermatophores".

In the Auchenipteridae and Ageneiosidae, the sperm nucleus is especially elongated and seems to be - at least for its shape and length (no ultrastructural data)-intermediate between that of viviparous Atheriniformes and that of Chondrostean fishes. In addition, at least in Tatia brunnea, it is lightly helical 
Table 2. - Summary of some features of the male reproductive biology in the studied families and genera of Siluriformes.

\begin{tabular}{|c|c|c|c|c|c|c|c|}
\hline & \multirow{2}{*}{$\begin{array}{l}\text { Testis } \\
\text { shape }\end{array}$} & \multicolumn{2}{|c|}{ Seminal vesicles } & \multirow[t]{2}{*}{ Deferent ducts } & \multirow{2}{*}{$\begin{array}{l}\text { Other } \\
\text { organs }\end{array}$} & \multirow{2}{*}{$\begin{array}{l}\text { Spermato. } \\
\text { shape }\end{array}$} & \multirow[t]{2}{*}{ Fertilization } \\
\hline & & Shape & $\mathrm{Spz}$ & & & & \\
\hline Helogeneidac & elongated & 0 & & very short & 0 & $S$ & $E$ \\
\hline Ariidae & elongated & 0 & & tubular & 0 & S & $\mathrm{E}$ \\
\hline Bagridae & foliated & small lobes & + or 0 & tubular convoluted & 0 & $\mathrm{~S}$ & $\mathrm{E}$ \\
\hline \multicolumn{8}{|l|}{ Pimelodidae } \\
\hline $\begin{array}{l}\text { Pimelodella } \\
\text { Pimelodus }\end{array}$ & lobes & small lobes & + or 0 & tubular & 1 pouch & $S$ & $\mathrm{E}$ \\
\hline Pseudopimelodus & small lobes & small lobes & 0 & $\begin{array}{l}\text { tubular then subdiv. } \\
\text { by villi with GC }\end{array}$ & 0 & $S$ & $\mathrm{E}$ \\
\hline Rhamdia & $\begin{array}{l}\text { numerous } \\
\text { thin lobes }\end{array}$ & $\begin{array}{l}\text { muscles } \\
\text { surround lobes }\end{array}$ & 0 & 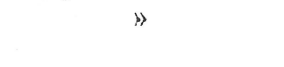 & 2 pouches & Ov. & $\mathrm{E}$ \\
\hline Loricariidae & $\begin{array}{l}\text { thin, } \\
\text { elongated }\end{array}$ & $\begin{array}{l}\text { post. part } \\
\text { of testes }\end{array}$ & + or 0 & $»$ & 0 & $S$ & $\mathrm{E}$ \\
\hline \multicolumn{8}{|l|}{ Callichthyidae } \\
\hline Corydoras & elongated & idem & 0 & tubular & 0 & $\mathrm{~S}$ & $\mathrm{E}$ \\
\hline Hoplosternum & elongated & $\begin{array}{l}\text { packed around } \\
\text { main duct }\end{array}$ & + or 0 & 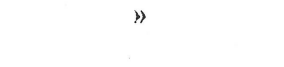 & 0 & S & $\mathrm{E}$ \\
\hline \multicolumn{8}{|l|}{ Auchenipteridae } \\
\hline Paraucheniplerus & $\begin{array}{l}\text { numerous } \\
\text { lobes }\end{array}$ & lobes ( 2 types) & $\begin{array}{c}\text { Ant } 0 \\
\text { post }+\end{array}$ & $\begin{array}{l}\text { tubular + large } \\
\text { subdiv. ampulla }\end{array}$ & 0 & Elo & I \\
\hline Pseudauchenipterus & $\begin{array}{l}\text { several } \\
\text { lobes }\end{array}$ & lobes & + & $\begin{array}{l}\text { tubular }+ \text { subdiv. } \\
\text { ampulla }\end{array}$ & 0 & Elo & I \\
\hline Auchenipterus & foliated & $\begin{array}{l}\text { packed around } \\
\text { main duct }\end{array}$ & + or 0 & tubular & 0 & Elo & I \\
\hline Ageneiosidae & $\begin{array}{l}\text { numerous } \\
\text { lobes }\end{array}$ & 0 & & $\begin{array}{l}\text { tubular + large } \\
\text { subdiv. ampulla }\end{array}$ & $\begin{array}{l}2 \text { pouches } \\
\text { with } G C\end{array}$ & Elo & I \\
\hline
\end{tabular}

Abbreviations: E: external fertilization; Elo: elongated sperm nucleus; GC: goblet cells; I: internal fertilization; 0: absence of spermatozoa; Ov.: ovoid sperm nucleus; S: spherical sperm nucleus; + : spermatozoa present in the seminal vesicles.

like the sperm nucleus of the Rajidae and Scylliorhinidae. Since there could be a relationship between such an elongated nucleus and the presence of original DNA-associated proteins (sulphur-containing protamines; Gusse and Chevaillier, 1981), it would be interesting to know which proteins are present in the sperm nuclei of Auchenipteridae and Ageneiosidae. In any case, the presence of elongated sperm nuclei, a gonopodium and internal fertilization in these two catfish families, while all the others have round sperm nuclei and spawn in the water, represents a small "revolution" in catfish evolution. It could have taken place in a common unknown ancestor arisen from the Pimelodidae (Chardon, 1968; fig. 2). From this point of view, it should be noted that the sperm nucleus in Rhamdia quelen-though this species is considered to be a primitive Pimelodid - is not spherical but slightly elongated.

The studied Auchenipteridae and Ageneiosidae exhibit two other original reproductive features. Inside the testis lobes spermatogenic tubules are radia$11 y$-oriented and the efferent ducts are longitudinally disposed on the surface of each lobe. In the females, the spermatozoa are stored throughout the ovary. This is in contrast with, for instance Poecilia reticulata (Jalabcrt and Billard, 1969) where the spermatozoa are stored in an antero-dorsal seminal receptacle. Spermatozoa are either free between the lamellae or localized in differentiated invaginations which could have a secretory activity, or they are inserted by the head in the epithelial cells. In the guppy, such a relationship with the epithelial cells allows spermatozoa to retain their viability for several months. We do not know how long spermatozoa remain alive in the ovary in the two catfish families, nor how and when the oocytes are fertilized.

\section{Organization of the male reproductive tract}

Among the catfish species that we have studied, Helogenes marmoratus and the $\Lambda$ riidae are considered as being the most primitive (see Chardon, 1968, Gosline, 1975; fig. 2). It appears that they effectively have the simplest male tract: only testicular tissue and a well-defined deferent duct in the Ariidae, are present ( fig. 1).

In Loricariidae and Callichthyidae the schematic morphology of the male tract is more or less unchanged, while in Bagridae and Pimelodidae the "testes" are segmented into several either flattened or approximately tubular lobes ( fig. 1). Whatever the tract morphology is, structures more or less individualized but which exhibit characters of seminal vesicles are present in these four families. They consist of tubules, without spermatogenic cells, lined by an epithelium having a rather high secretory activity. What is especially interesting in these four families, is the topographical - but also the structural and histological-relationships between the testicular tissue and the vesicular tissue. Indeed, going from the front 


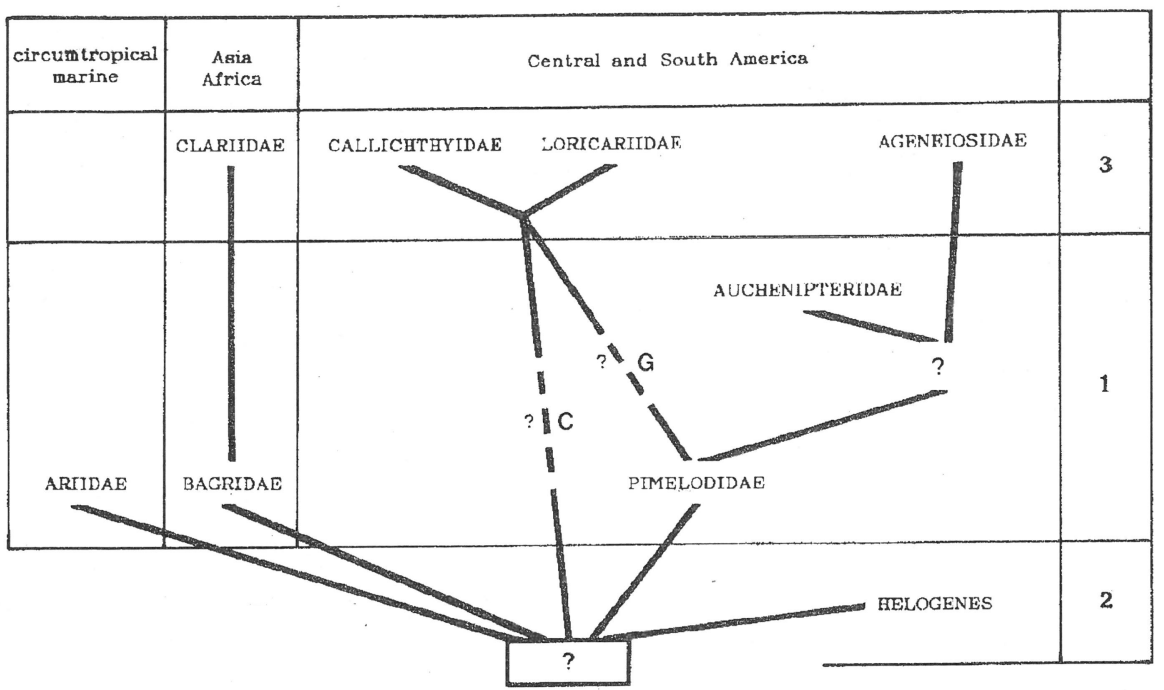

Figure 2. Summary of the working hypotheses concerning evolution of the eight Catfish families cited in this study, from Chardon $(1968, C)$ and Gosline (1975, G). Evolutionary steps from Chardon: 1) entire and free swimmbladder; 2) reduced and free swimbladder; 3) reduced and at least partially enclosed swimbladder. toward the rear of the tract, and starting from the main duct, the round germ cells disappear progressively from the tubules. Finally, either a small number of germ cells remain present (restricted to the apex of the tubules: Bagridae and Loricariidae; some germ cells scattered everywhere: Corydoras $\mathrm{sp}$.) or they become completely absent (Hoplosternum sp. and Pimelodidae). Then, the remaining epithelial cells, supposed to be homologous to Sertoli cells, reinforce their secretory activity (which may be very discrete when germ cells are present). In addition, they probably secrete different molecules such as polysaccharides, proteins and phospholipids which would be present in the seminal vesicle fluid (Van den Hurk et al., 1987). Another implication of the common origin of the testicular tissue and of the seminal vesicles is that the interstitial cells in the vesicles are homologous to Leydig cells in the testis. The steroidogenic activity of these interstitial cells has been extensively demonstrated in Clarias gariepinus (Schoonen and Lambert, 1986). These conclusions are in agreement with data indicating that both testis and seminal vesicles develop from the genital ridge (Sneed and Clemens, 1963).

According to Gosline (1975), Pimelodidae gave rise to most of the modern catfishes present in South America, while Chardon (1968) has proposed two different origins (fig. 2). Our observations do not provide definitive arguments for either of the two hypotheses, but the consideration of the organization and morphology of the male tracts would rather argue in favour of the second.

In addition to the presence of a gonopodium, male tracts of Auchenipteridae are characterized by 1) a differentiation of the deferent duct in a more or less dilated ampulla subdivided by villi, 2) a clear- cut topographical and histological distinction between testes and seminal vesicles, while there is a progressive transition between both tissues in the supposed ancestors: the Pimelodidae. Although both catfish evolutions were geographically independent (Gosline, 1975), the same situation takes place also in Clariidae (Van den Hurk et al., 1987) as compared with the Bagridae which are supposed to have given rise to them.

The Ageneiosidae are characterized by the disappearance of the seminal vesicles which, however, seem to be replaced 1) by the acquisition of a secretory activity by the deferent duct differentiated in an ampulla, and 2) by the two glandular appendices. This organization, coupled with elongated sperm nuclei and internal fertilization, could correspond to the most advanced evolutionary step of the male reproductive tract in the Siluriformes.

\section{Sperm storage}

Our observations suggest that in mature males there are species- or family-specific differences in the relationships that sperm cells establish temporarily, with the seminal vesicles and with the secretion: either spermatozoa are present exclusively in the basal parts of the seminal vesicular tubules or they are present everywhere along the tubules, mixed with secretory material. While in several species, the spermatozoa are stored for some time in the seminal vesicles, in others, the function of sperm storage may be assumed-either uniquely or in addition to the seminal vesicles-by other structures. This is true for the pouch present in some Pimelodidae and for the large subdivided deferent duct present in Pseudopimelodus raninus and in Ageneiosus brevifilis.

In the Auchenipteridae and Ageneiosidae, ovaries exhibit cellular or structural differentiations similar 
to those observed in the male tract to maintain the fertility of the spcrm cells during storage. Indeed, spermatozoa are either inserted in the epithelial cells or/and embedded in a secretory material either produced by the ovarian epithelial cells (Pimelodus ornatus) or, perhaps, of male origin ( $P$. galeatus, A. brevifilis).

\section{Acknowledgements}

We are grateful to Dr. Le Gac and to D. Torvic for their assistance in collecting specimens, to H. Saurin who gave us Chrysichthyis nigrodigitatus genital tracts, to M. L. A. Loir for her efficient help with the literature and to J. Y. Lefeuvre for excellent assistance in preparing figures. This work was supported by the French National Institute for Agronomical Research (AIP-INRA Biologie et Ecologie des Poissons Guyanais d'intérêt aquacole).

\section{REFERENCES}

Billard R., 1986. Spermatogenesis and spermatology of some teleost fish species. Reprod. Nutr. Develop., 26, 877 . 920.

Breder C. M., D. E. Rosen, 1966. Modes of reproduction in fishes. Natural History Press, New York, 941 p.

Chacon J. O., A. Mendes Filho, 1972. Estudo morfologico do aparelho genital de cangati, Trachycorystes galeatus Linnacus, 1756 (Pisccs, Aucheniptcridac). Rev. Cienc. Cult., 24, 531-536.

Chardon M., 1968. Anatomie comparée de l'appareil de Weber et des structures connexes chez les Siluriformes. Ann. Musée Royal Afrique Centrale, 169, 1-277.

Gosline W., 1975. The palatine-maxillary mechanism in catfishes, with comments on the evolution and zoogeography of modern siluroids. Occ. pap. Calif. Acad. Sci., 120, $1-31$.

Grier H. J., 1981. Cellular organization of the testis and spermatogenesis in fishes. Am. Zool., 21, 345-357.
Gusse M., P. Chevaillier, 1981. Microelectrophoretic analysis of basic protein changes during spermiogenesis in the dogfish Scylliorhinus caniculus. Exp. Cell Res., 136, 391397.

Jalabert B., R. Billard, 1969. Étude ultrastructurale du site de conservation des spermatozoïdes dans l'ovaire de Poecilia reticulata (Poisson teleosteen). Ann. Biol. Anim. Bioch. Biophys., 9, 273-280.

Schoonen W. G. E. J., J. G. D. Lambert, 1986. Steroid metabolism in the seminal vesicles of African catfish Clarias gariepinus (Burchell), during the spawning season; under natural conditions and kept in ponds. Gen. Comp. Endocrinol., 61, 355-367.

Sneed K. E., H. P. Clemens, 1963. The morphology of the testes and accessory reproductive glands of the catfishes (Ictaluridae). Copeia, 1963; 606-611.

Van den Hurk R., J. W. Resink, J. Peute, 1987. The seminal vesicle of the African catfish, Clarias gariepinus. A histological, histochemical, enzyme-histochemical, ultrastructural and physiological study. Cell Tissue Res., 247, 573582. 